\title{
PENGARUH ETIKA DAN MORAL REMAJA TERHADAP LUNTURNYA LITERASI DI ERA DIGITAL
}

\author{
Yuki Heriyanto ${ }^{1}$, Kendra Camilla Besariani ${ }^{2}$, Raisya Ghina Zahira ${ }^{3}$, Puan Enva Sabina ${ }^{4}$, Moses \\ Glorino Rumambo Pandin ${ }^{5}$ \\ Bahasa dan Sastra Inggris, Fakultas Ilmu Budaya, Universitas Airlangga \\ yuki.heriyanto-2020@fib.unair.ac.id, ken.camilla.besariani-2020@fib.unair.ac.id, \\ raisya.ghina.zahira-2020@ fib.unair.ac.id, puan.enva.sabina-2020@ fib.unair.ac.id, \\ moses.glorino@fib.unair.ac.id
}

\begin{abstract}
This study aims to determine the implication of adolescent ethics and morals that can cause literacy to fade in the digital era. The method used is a descriptive qualitative method that utilizes the type of library research, namely by examining several reference sources involve journals, the internet from relevant agencies, etc. The results of this study indicate that based on 6 keywords such as insecure, jamet, gelay, ghosting, ikoy-ikoyan, and cepu, could concluded that the curiosity of netizens who are dominated by teenagers represents a bad phenomenon around them, except ikoy-ikoyan. This can also trigger moral degradation in adolescents because they behave to be more sensitive to the environment but tend to maintain their own ego. Nowadays, teenagers have become more responsive to negative issues which become exciting when they are raised or communicated with those closest to them. From this study, it can be concluded that the degradation of ethics and morals that occurs especially among teenagers really reduces the quality of literacy in the digital era. This is an event that is very concerning for the lives of young people as the nation's successors if this phenomenon continues. Human relations are also used as material relations, because netizens, especially teenagers, prefer to enjoy the virtual world rather than the real world.
\end{abstract}

Keyword: Ethic, Moral, Digital Literacy, Technology

\begin{abstract}
ABSTRAK
Penelitian ini bertujuan untuk mengetahui pengaruh etika dan moral remaja yang mampu menyebabkan lunturnya literasi di era digital. Metode yang digunakan adalah metode kualitatif deskriptif yang memanfaatkan jenis penelitian kepustakaan, yakni dengan menelaah beberapa sumber referensi meliputi jurnal, internet dari instansi relevan, dan sebagainya. Hasil pada penelitian ini mengindikasikan bahwa berdasarkan 6 keyword seperti insecure, jamet, gelay, ghosting, ikoy-ikoyan, dan серu, maka dapat dipetik bahwa rasa penasaran para warganet yang didominasi oleh kaum remaja merepresentasikan fenomena buruk yang ada di sekitarnya, kecuali ikoy-ikoyan. Hal ini pun dapat memicu terjadinya degradasi moral pada remaja karena mereka bersikap untuk lebih sensitif terhadap lingkungan tetapi cenderung mempertahankan ego mereka sendiri. Akhir-akhir ini remaja menjadi lebih responsif terhadap isu-isu negatif yang menjadi seru apabila dilontarkan atau dikomunikasikan dengan orang-orang terdekat di lingkungan mereka. Dari penelitian ini dapat disimpulkan bahwa degradasi etika maupun moral yang terjadi khususnya di kalangan remaja benar-benar menurunkan kualitas literasi di era digital. Sehingga hal ini menjadi peristiwa yang sangat memprihatinkan bagi kehidupan pemuda sebagai penerus bangsa
\end{abstract}


apabila fenomena ini terus dibiarkan. Relasi manusia pun dijadikan sebagai relasi kebendaan, karena para warganet khususnya remaja lebih senang menikmati dunia maya daripada dunia nyata.

Kata Kunci: Etika, Moral, Literasi Digital, Teknologi.

\section{PENDAHULUAN}

\section{Latar Belakang}

Manusia adalah salah makhluk sosial yang harus berperan dalam menjalani interaksi yang baik dengan sesama manusia yang lainnya. Karena tanpa adanya interaksi baik tersebut, maka semua aktivitas yang dijalani akan terasa begitu berat. Dalam menjalani aktivitas tersebut, terdapat suatu kebutuhan primer supaya memudahkan kinerja manusia, yakni kebutuhan akan informasi. Informasi sudah ada sejak zaman purba, yakni dengan memanfaatkan media berupa dinding-dinding goa yang biasanya didominasi oleh pengalaman berburu beserta hewan buruannya. Bahkan pada era 500 SM, orang Mesir kuno sudah beralih ke kertas papyrus dan dikembangkan lagi oleh orang Cina yang menemukan kertas dari serat bambu yang mulai bisa ditulis oleh tinta dan juga dicetak dalam jumlah yang banyak. Tetapi seiring perkembangan zaman, penyebaran informasi sudah sangat praktis untuk dilakukan, tentu saja berkat adanya internet, sebuah informasi mengenai peristiwa yang baru saja terjadi maka akan

\footnotetext{
${ }^{1}$ Taopan, Y. F., Oedjoe, M. R., \& Sogen, A. N. (2019).
}

disampaikan pada saat itu juga kepada para penerima informasi yang membutuhkan informasi mengenai peristiwa tersebut.

Rangkaian peristiwa maupun kasus yang terjadi baik itu di masa kini juga masa lampau tentu saja meninggalkan berbagai problematika dan kasus yang harus ditemukan solusinya. Oleh karena itu, maka pemikiran secara kritis pun memiliki urgensi yang sangat penting untuk dimiliki oleh setiap insan manusia agar mereka mampu menyaring informasi mana yang layak untuk diserap dan mana yang layak untuk disingkirkan. Di samping itu, manusia pun harus dibekali dengan kemampuan melek terhadap teknologi supaya mampu dalam merancang, membuat, menyeleksi, dan menggunakan hasil-hasil rekayasa teknologi ${ }^{1}$.

Informasi juga tidak luput dari dunia literasi, karena dalam mencerna sebuah informasi diperlukan keterampilan berupa membaca dan menafsirkan sesuatu. Kemudian dari hasil tafsir tersebutlah yang akan dikomunikasikan atau disampaikan 
kepada orang lain sebagai salah satu bentuk kegiatan manusia sebagai makhluk sosial².

Ketika manusia sedang mengalami masa remaja, yang baik itu mengalami transisi secara fisik maupun psikis adalah sebuah masa dimana mereka mencari jati diri mereka. Jati diri yang baik akan segera tercapai apabila lingkup pergaulan remaja tersebut membawa dampak yang baik pula kepada remaja tersebut. Tetapi dari proses pencarian jati maupun identitas diri tersebut dapat menimbulkan suatu kasus yang bernama cyberbullying (Nur Maya, 2015 dalam Fahlevi, et al. 2020) ${ }^{3}$. Umumnya kasus cyberbullying diakibatkan oleh rusaknya tatanan sosial dan budaya di kalangan masyarakat.

Ezziane (2007) dalam Taopan, et al. (2019) menyampaikan bahwa Information of Technology (IoT) literacy is the key to today's empowerment and that education is the best foundation of $i t^{4}$. Serta menurut Kurniawati \& Baroroh, (2016) dalam Candrasari et al. (2020) mengungkapkan bahwa literasi digital merupakan sikap, kemampuan, serta ketertarikan individu yang memanfaatkan teknologi digital dalam

\footnotetext{
${ }^{2}$ Fatimah, M. M., et al. (2020). hlm. 62

${ }^{3}$ Fahlevi, R. Y., Yusuf, A., Krisnana, I. (2020). hlm. 39.
}

bentuk kegiatan mengakses, menganalisis, mengelola, mengintegrasikan, dan membangun pengetahuan baru ${ }^{5}$. Literasi digital tentu saja tidak bisa lepas dari kehidupan kita, karena pada era transformasi digital seperti saat ini sangat bergantung kepada informasi yang hampir seluruhnya bergantung kepada teknologi. Terlebih lagi ketika wabah pandemi virus Covid-19 yang menuntut terjadinya pola perubahan bagi segala aspek kehidupan manusia, akselerasi utilisasi teknologi pun semakin terimplementasikan.

Transformasi digital tidak hanya membawa pengaruh baik kepada kehidupan masyarakat, tetapi juga diiringi dengan pengaruh buruk. Pengaruh baik dari transformasi digital didominasi oleh seluruh kegiatan yang menjadi praktis, sedangkan pengaruh buruknya tentu saja ditimbulkan dari manusia sebagai pihak yang menciptakan dan juga menikmati pengaruh dari transformasi digital itu sendiri yang disebabkan oleh krisis etika dan moral yang dilandasi oleh ego manusia itu sendiri.

Pengguna internet di Indonesia dianggap sebagai pengguna pasif, karena

\footnotetext{
${ }^{4}$ Taopan, Y. F., Oedjoe, M. R., \& Sogen, A. N. (2019). hlm. 63.

${ }^{5}$ Candrasari, Y. E., et al. (2020). hlm. 613.
} 
mereka bersikap konsumtif atau hanya menikmati kecanggihan fitur berbagai aplikasi yang ditawarkan oleh teknologi, tanpa disertai dengan pemanfaatan teknologi yang efisien. Salah satu unsur penyebab dari peristiwa tersebut adalah kurangnya individual competence yang dimiliki oleh pengguna internet khususnya kaum remaja, yang dimana mereka masih belum begitu memahami dan mengoperasikan media dengan optimal, juga lemahnya kemampuan berpikir kritis yang sangat berkontribusi dalam menyeleksi informasi konten yang bermunculan di sosial media ${ }^{6}$. Aktivitas berselancar di dalam sosial media pun memonopoli kehidupan para pemuda sebagai bentuk dari kedigdayaan teknologi dalam mengalihkan peran relasi manusia menjadi relasi kebendaan?.

\section{Rumusan Masalah}

Berdasarkan pemaparan pendahuluan di atas, maka penelitian ini dirumuskan ke dalam permasalahan sebagai berikut:

1. Bagaimana kualitas etika dan moral yang berdampak terhadap daya tangkap remaja pada literasi digital?

\footnotetext{
${ }^{6}$ Ibid, hlm. 612.

${ }^{7}$ Fatmawati. (2020). hlm. 95.
}

2. Bagaimana representasi etika dan moral remaja dalam mengakses internet?

\section{Kajian Literatur}

Penelitian ini menggunakan referensi dari beberapa penelitian. Penelitian pertama adalah dari Taopan et al. dengan judul Dampak Perkembangan Teknologi Informasi dan Komunikasi terhadap Perilaku Moral Remaja di SMA Negeri 3 Kota Kupang (2019) ${ }^{8}$ yang berfokus kepada pengaruh penggunaan gawai dan internet yang mempengaruhi moralitas kalangan pelajar serta upaya yang telah dilakukan keluarga, sekolah, juga masyarakat dalam membentengi pelajar dari dampak negatif penggunaan gawai dalam rangka memberi solusi terhadap perilaku moral pelajar SMAN 3 Kupang. Dari penelitian ini ditemukan bahwa utilitas gadget menimbulkan dampak positif maupun negatif terhadap sisi kognitif juga perilaku moral siswa.

Penelitian kedua adalah milik Fatimah, et al. dengan judul Meningkatkan Pemahaman Wawasan Kebangsaan Peserta Didik melalui Literasi Digital dalam Pembelajaran PPKn (2020) ${ }^{9}$ berfokus kepada gambaran yang relevan dengan literasi digital untuk meningkatkan

\footnotetext{
${ }^{8}$ Taopan, Y. F., Oedjoe, M. R., \& Sogen, A. N. (2019).

${ }^{9}$ Fatimah, M. M., et al. (2020).
} 
pemahaman wawasan kebangsaan terhadap Pendidikan Kewarganegaraan era revolusi industri 4.0 pada pelajar kelas X SMA Laboratorium Percontohan UPI Bandung. Dari penelitian ini ditemukan hasil bahwa dengan diterapkannya wawasan kebangsaan pada pelajar, maka terjadilah peningkatan pemahaman dalam pelajaran Pendidikan Kewarganegaraan, sehingga dapat dikategorikan sebagai "sangat baik" dalam cakupan kelompok maupun individu.

Penelitian ketiga adalah milik Catur Nugroho dan Kharisma Nasionalita yang berjudul Indeks Literasi Digital Remaja di Indonesia (2020) ${ }^{10}$ yang berfokus untuk mengetahui indeks literasi digital remaja di Indonesia. Kemudian penelitian ini membuktikan bahwa remaja yang berdomisili di kota Bandung, Denpasar, Pontianak, dan Surabaya memanfaatkan teknologi serta media digital dengan cukup baik dalam kegiatan berkomunikasi, berkreatifitas, mencari serta menyeleksi informasi yang tepat.

Penelitian keempat adalah milik Emilia Susanti, et al. dengan judul Sosialisasi Membangun Karakter Berbasis Pancasila di Era Digital 4.0 dalam Upaya Pencegahan

\footnotetext{
${ }^{10}$ Nugroho, C., Nasionalita, K. (2020).

${ }^{11}$ Susanti, E. (2020).
}

Radikalisme dan Terorisme pada Remaja $(2020)^{11}$ yang berfokus dalam membangun literasi karakter pelajar SMAN 1 Tuba dengan berbasis Pancasila. Hasil pada penelitian ini yakni dengan diterapkannya kegiatan sosialisasi maka dapat meningkatkan kesadaran beserta pemahaman siswa maupun pihak sekolah terhadap aspek hukum pidana khususnya dalam utilitas media sosial bagi kalangan remaja.

Penelitian kelima adalah milik Yuli Candrasari, et al. dengan judul Pengembangan dan Pendampingan Literasi Digital untuk Peningkatan Kualitas Remaja dalam menggunakan Internet (2020) ${ }^{12}$. Penelitian ini berfokus kepada penerapan kegiatan pemberdayaan masyarakat dalam bentuk kegiatan diskusi serta simulasi dengan upaya agar masyarakat mampu mengaplikasikan literasi digital secara sehat, khususnya kaum ibu dalam mendampingi putra-putrinya. Kemudian penelitian ini mengindikasikan bahwa para remaja di kawasan tersebut mampu untuk menahan diri dengan tidak mengunggah seluruh informasi mengenai dirinya masing-masing, sehingga melindungi dirinya dai bahaya kebocoran privasi di dunia maya.

\footnotetext{
${ }^{12}$ Candrasari, Y. (2020).
} 
Tujuan Penelitian

Penelitian ini bertujuan untuk mengetahui pengaruh etika dan moral remaja yang mampu menyebabkan lunturnya literasi di era digital.

\section{$H_{1}$ : Kualitas etika dan moral yang} berdampak terhadap daya tangkap remaja pada literasi digital

Etika dan moral adalah dua unsur yang sekilas terlihat serupa, tetapi sebenarnya berbeda. Pada penelitian ini akan dipaparkan apakah etika dan moral memiliki implikasi atau tidak terhadap kemampuan literasi digital khususnya para remaja.

\section{$\mathrm{H}_{2}$ : Pencarian Keyword di internet merepresentasikan etika dan moral remaja}

Ketika kita ingin mencari suatu keyword internet, maka hasil yang akan ditemukan tentu saja menjawab rasa penasaran atau memenuhi kebutuhan kita terhadap suatu informasi.

\section{METODOLOGI PENELITIAN}

\section{Tujuan Metodologi Penelitian}

Penelitian ini bertujuan untuk mengetahui implikasi etika dan moral terhadap lunturnya literasi digital. Metode yang digunakan pada studi ini ialah kualitatif

\footnotetext{
${ }^{13}$ Syarifurrizal, E. (2021). hlm. 429.
}

deskriptif yang memanfaatkan jenis penelitian kepustakaan, yakni dengan menelaah beberapa sumber referensi meliputi jurnal, internet dari instansi relevan, dan sumber lainnya ${ }^{13}$. Berdasarkan pemaparan dari Sugiyono (2017) yang mengungkapkan bahwa metode kualitatif adalah sebuah penelitian yang berlandaskan filsafat postpositivisme, untuk mengkaji kondisi objek ilmiah untuk memahami interpretasi makna, fenomena, serta menemukan hipotesis ${ }^{14}$. Metode kualitatif deskriptif digunakan pada penelitian ini karena mengandalkan pemaparan data secara sistematis mengenai suatu kejadian atau situasi yang dikumpulkan. Sehingga peneliti menggunakan metode ini demi menggambarkan rincian yang relevan dengan moralitas remaja di era digital.

\section{Populasi Penelitian}

Populasi yang diambil pada penelitian ini adalah berasal dari kalangan remaja karena mereka adalah kaum mayoritas dari penduduk Indonesia yang paling aktif dalam menggunakan teknologi internet. Selain itu, masa remaja adalah sebuah masa dimana manusia sedang gencar-gencarnya mencari jati diri agar semakin dikenal oleh orang-

\footnotetext{
${ }^{14}$ Sugiyono. (2017). hlm. 19.
} 
orang di sekelilingnya dengan cara berkontribusi aktif dalam media sosial.

\section{Tempat dan Waktu}

Penelitian ini tidak mengambil data di lapangan dan mengumpulkan data dari beberapa literatur yang relevan yang didominasi oleh referensi secara daring. Sedangkan periode waktu yang digunakan adalah data yang terjadi pada tahun 2021 .

\section{Teknik Pengumpulan Data}

Data dikumpulkan dengan cara membaca beberapa referensi yang relevan, kemudian mencari data yang sesuai dengan isu dan permasalahan penelitian, yang akan dilanjutkan oleh tahap analisa data.

Penelitian ini akan menganalisa 6 keyword populer dan seberapa banyak ratarata orang mengakses keyword tersebut sepanjang 2021.

\section{Teknik Analisis Data}

Terdapat tiga tahapan ketika menganalisa data penelitian secara kualitatif menurut Milles dan Hubarman (2013) ${ }^{15}$, yakni:

- Reduction (Reduksi data)

Peneliti mereduksi data sehingga yang terseleksi adalah data yang relevan dengan penelitian ini. Atau dengan kata lain, mereduksi data adalah kegiatan untuk menyortir data.

Dari data yang dikumpul, kemudian peneliti menyortir data 12 bulan sepanjang 2021 menjadi 5 bulan saja, yakni Januari, Februari, Maret, Agustus, dan Oktober (berdasarkan bulan yang mengalami kelonjakan pencarian keyword).

- Display (Pemaparan data)

Menyusun informasi serta menyajikan gambaran data secara menyeluruh, contohnya dalam bentuk tabel dan grafik.

- Conclution drawing and Verifying (Penarikan kesimpulan serta verifikasi)

Langkah ini dilakukan sebagai tahap akhir dalam menganalisis data dan tidak lupa juga untuk diperiksa kembali validitas datanya sehingga data yang ditampilkan adalah data yang akurat.

\section{HASIL DAN PEMBAHASAN}

Penelitian ini menguji beberapa variabel, seperti kualitas etika, moral, dan keyword pada mesin pencarian di internet.

\footnotetext{
${ }^{15}$ Milles, B., Huberman, A. M. (2013).
} 
Pengaruh Kualitas Etika dan Moral yang

Berdampak terhadap Daya Tangkap

Remaja pada Literasi Digital

Bangsa yang unggul tentu saja dipengaruhi oleh kualitas etika serta moral masyarakatnya, terutama kaum remaja sebagai generasi muda penerus bangsa. Menurut KBBI, etika adalah ilmu mengenai sesuatu yang baik dan buruk serta mengenai hak dan kewajiban moral (akhlak). Sedangkan moral adalah sebuah ajaran atau kaidah mengenai akhlak, budi pekerti, kewajiban, sikap, susila, perbuatan, dan sebagainya ${ }^{16}$.

Menurut Menkominfo RI, Johnny G. Plate (2021) mengungkapkan bahwa pendayagunaan konektivitas internet beserta lalu lintas internet menjadi pemicu bagi kemajuan yang inklusif di era New Normal. Di samping itu, terjadi juga beberapa fenomena yang miris di balik kecanggihan dunia digital, contohnya seperti bebasnya konten berbau seksualitas pada website, maraknya kasus pelecehan seksual, penipuan online (pinjaman uang, jual-beli, penipuan jasa, dan sebagainya).

Tentu saja hal ini dipengaruhi oleh lemahnya penghayatan nilai-nilai character building yang diperoleh di bangku akademis.
Terlebih lagi sistem kurikulum di Indonesia yang masih memprioritaskan teori kognitif yang lebih mengarah kepada kegiatan hafalan daripada praktik di lapangan yang sebenarnya jauh lebih efektif daripada kurikulum kognitif. Yang terlebih memprihatinkan lagi ilmu yang telah diperoleh semasa bangku sekolah pada kenyataannya tidak begitu terpakai di dunia kerja, sehingga mengakibatkan ilmu wawasan kebangsaan para remaja di saat mereka tumbuh menjadi dewasa nanti malah semakin luntur.

Konsumsi konten yang bernuansa negatif menjadikan remaja lebih terbiasa untuk mendukung hal-hal negatif, juga lebih gemar mengonsumsi kabar yang mengandung unsur clickbait sehingga warganet hanya membaca berita hanya berdasarkan judulnya saja yang menarik perhatian membaca dan menonjolkan isu yang menyoroti fenomena buruk dari seseorang. Padahal isi konten artikel berita tersebut belum tentu berisikan konten yang negatif. Dari judul berita tersebut dapat menimbulkan asumsi negatif bagi para warganet sehingga ikut dibagikan juga kepada teman dan rekannya, sehingga hal ini juga mampu menimbulkan hoax. Hoax pun

\footnotetext{
${ }^{16}$ KBBI V. (2016).
} 
dapat menimbulkan perpecahan atau disintegrasi apabila ditanggapi dengan terlalu serius dan tanpa memperhatikan validitas sumber berita tersebut.

Negara Indonesia memang dikenal dengan sistem pergaulannya yang lebih peduli terhadap sesama daripada luar negeri yang cenderung bersikap individualistis.

Tetapi seiring perkembangan zaman, apabila relasi antar manusia yang beralih menjadi relasi kebendaan masih terus dipertahankan maka akan melunturkan nilai sosial dan budaya asli para pendahulu kita. Apalagi negara Indonesia yang sudah lama dikenal sebagai negara yang menganut ideologi Pancasila yang menganut kepada 5 sila yang menjadi falsafah kehidupan para generasi pendahulu kita.

\section{Representasi Etika dan Moral Remaja dalam mengakses Internet}

Sepanjang kaleidoskop 2021 lalu, muncul beberapa trending keyword sebagai representasi dari rasa penasaran masyarakat terhadap sesuatu, yakni komorbid, insecure, jamet, gelay, mletre, ghosting, ikoy-ikoyan, серu, disleksia, dan lampor. Dari 10 keyword tersebut, yang paling sering disebut oleh remaja Indonesia pada tahun 2021 adalah insecure, jamet, gelay, ghosting, ikoy-ikoyan, dan cepu. Dari 6 istilah tersebut, terlampir angka pencarian digambarkan dalam tabel dan grafik seperti berikut:

\begin{tabular}{lccccc}
\multicolumn{5}{c}{ Tabel 1 Pencarian Keyword Populer pada beberapa bulan } \\
tertentu \\
\hline Keyword & \multicolumn{5}{c}{ Bulan } \\
& Jan & Feb & Mar & Agt & Okt \\
Insecure & 44 & 35 & 28 & 21 & 20 \\
Jamet & 7 & 11 & 9 & 8 & 14 \\
Gelay & 0 & 100 & 16 & 8 & 14 \\
Ghosting & 13 & 13 & 47 & 17 & 13 \\
Ikoy-ikoyan & 0 & 0 & 0 & 20 & 1 \\
Cepu & 11 & 13 & 9 & 16 & 23 \\
\hline
\end{tabular}

(Sumber: Google Trends)

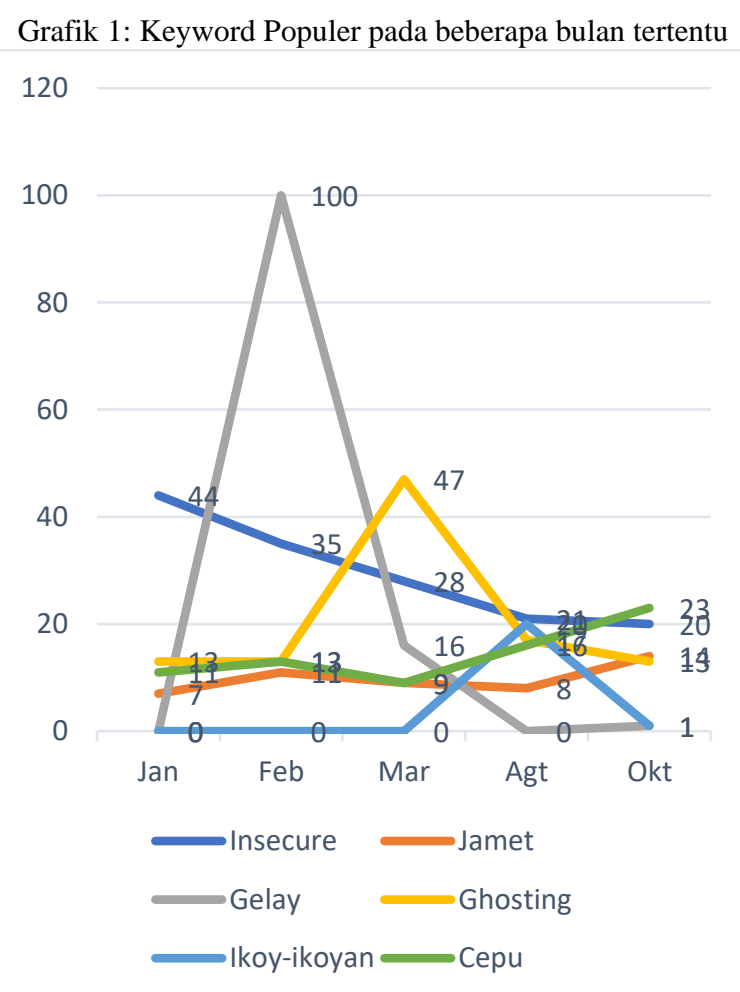

\section{Insecure}

Menurut Oxford Dictionary, kata insecure merujuk ke ungkapan rasa cemas atau ketidakpercayaan terhadap diri sendiri. 
Rasa cemas tersebut timbul dari lingkungan sosial yang sebagian masyarakat terutama yang berasal dari kalangan ekonomi menengah ke atas cenderung sering memamerkan kebahagiaan maupun penampilan fisik mereka yang good looking ke sosial media. Sehingga penampilan mereka dijadikan sebagai patokan atau tolak ukur bahkan tren bagi semua kalangan masyarakat khususnya masyarakat kelas ekonomi menengah maupun ke bawah. Tentu saja hal ini cukup membuat masyarakat kalangan ekonomi ke bawah merasa semakin cemas akan kehidupannya.

Terutama di masa remaja yang sedang mencari jati diri, bahkan sebagian remaja berupaya untuk melakukan tindakan kriminal (misalnya tindakan pencurian atau penodongan) supaya hasil dari tindakan mereka tersebut mampu menghidupi dan memenuhi biaya kebutuhan dan keinginan mereka agar terlihat "wah" di sosial media.

Dari fenomena rersebut,
mengindikasikan bahwa masyarakat
Indonesia cenderung sering bersikap
mengeluh dan kurang mensyukuri terhadap
segala nikmat yang telah diberikan Tuhan.
Karena sebetulnya kita bisa menjadi bahagia
dengan diri kita sendiri, tanpa harus
mengikuti bahkan mengimitasi kehidupan

orang lain yang belum tentu pantas dengan kehidupan mereka. Lebih baik bertingkah laku yang sesuai dengan status finansial masing-masing dan lebih banyak mensyukuri segala nikmat yang ada.

Di sisi lain, pada tabel dan grafik sebelumnya, dipaparkan bahwa trafik tren insecure menunjukkan penurunan dari awal tahun ke akhir tahun. Sehingga menunjukkan penurunan rasa cemas terhadap diri sendiri dan cenderung bisa bersikap lebih mensyukuri kehidupan dan tidak begitu ingin mengimitasi kehidupan orang lain.

\section{Jamet}

Pada tabel dan grafik di atas, keyword jamet cenderung bersifat hampir stabil sepanjang tahun, karena lebih bersifat kepada kebudayaan sehari-hari. Istilah jamet merujuk kepada penampilan seseorang yang ingin tampak keren dengan menggunakan musik metal. Istilah jamet sendiri berasal dari dua macam gabungan kata yakni Jajak Metal dan Jawa Metal. Karakteristik seorang remaja maupun pemuda/i yang bisa disebut sebagai jamet meliputi memakai baju oversize yang bernuansa kehitaman, celana pensil yang kedodoran, memakai tindik, mewarnai rambut dengan warna mencolok, potongan rambut segitiga, sering berkumpul dengan 
alasan yang tidak jelas, suka joget, dan sebagainya (USS Feed, 2021) ${ }^{17}$.

Istilah jamet sendiri sebetulnya tidak berada dalam bahasa baku bahkan KBBI. Karena jamet merupakan salah satu kata dari bahasa slang yang bertujuan untuk dilontarkan oleh kalangan remaja tertentu untuk menyindir seseorang secara implisit agar lawan bicaranya tidak terlalu mengetahui secara jelas mengenai istilah tersebut.

Di samping itu, dalam menggunakan istilah jamet seharusnya lebih memperhatikan konteks tersebut apakah layak untuk dilontarkan atau tidak, karena salah satu makna dari jamet yaitu Jawa Metal tentu saja bisa dianggap sebagai pelanggaran SARA karena merujuk ke salah satu suku, apalagi untuk orang yang tidak dikenal.

\section{Gelay}

Dari tabel tersebut dapat dilihat bahwa kata gelay yang paling banyak disorot, terutama pada Februari 2021. Dikarenakan warganet yang sedang gencar-gencarnya mencari informasi mengenai kabar seseorang yang berselingkuh, dan bisa juga merujuk ke merasa jijik ke suatu hal.

\footnotetext{
${ }^{17}$ USS Feed. (2021).
}

${ }^{18}$ Kompas TV. (2021).
Hal ini mengindikasikan bahwa warganet Indonesia gemar mencari tahu atau mengurus urusan rumah tangga orang lain. Bermulai dari ungkapan yang berasal dari seorang penyanyi religi Indonesia, Nissa Sabyan yang diisukan berselingkuh dengan rekan dalam satu bandnya, Ayus Sabyan. Para warganet yang merasa penasaran apakah dirinya benar berselingkuh atau tidak, lantas Nissa Sabyan merespon dengan ungkapan "Assalamualaikum, kalian nungguin aku nggak? Nggak mau, nggak suka gelay." (Kompas TV, 2021) ${ }^{18}$. Gelay adalah sebuah kata plesetan dari geli yang bermakna perasaan tubuh seseorang ketika digelitiki, atau ke ga like (tidak suka) sebagai ujaran untuk menolak sesuatu.

\section{Ghosting}

Menurut Oxford Dictionary ${ }^{19}$, kata ghosting merujuk kepada praktik untuk mengakhiri sebuah hubungan pribadi dengan seseorang secara tiba-tiba dan tanpa alasan yang meliputi semua komunikasi.

Isu ghosting pun viral karena berawal dari kisah Kaesang Pangarep yang dahulunya ingin menikahi mantan kekasihnya yang notabene hubungan mereka sudah berjalan selama 5 tahun, yakni dengan Felicia Tissue,

\footnotetext{
${ }^{19}$ Oxford Dictionary.
} 
tetapi malah meninggalkannya tanpa alasan yang jelas. Sehingga sebagian remaja yang pastinya pernah mengalami fenomena serupa merasa dirinya direpresentasikan oleh kisah perghostingan yang dilakukan oleh Kaesang tersebut.

\section{Ikoy-ikoyan}

Berawal dari kegiatan iseng yang dilakukan oleh salah satu influencer Indonesia, Arief Muhammad yang mengadakan aktivitas give away bagi penggemarnya sehingga Direct Messages yang masuk ke akun Instagram milik Arief Muhammad ada sebanyak 1 juta pesan. (Kompas, 2021).

Realitanya, istilah ikoy diambil dari nama panggilan salah satu asisten Arief Muhammad, yakni Muhammad Rizqi Fadhilah. Ketika Arief menggunggah storynya bersama Ikoy dalam rangka membagi uang dadakan tepatnya pada 1 Agustus 2021 lalu, Arief bertanya Koy, gimana jari lu udah keriting belum ngirimngirim?. Semakin sering Arief menyebutkan kata ikoy pada aktivitas bagi-bagi uang maupun giveaway lainnya, maka ikoy pun diidentikan dengan istilah giveaway, bahkan fenomena ini menyebar juga ke artis-artis lainnya.

\section{Cepu}

Berdasarkan data tabel di atas, istilah сери menjadi puncak tren pada bulan Oktober 2021, meskipun di beberapa bulan sebelumnya menunjukkan tren yang stabil. Fenomena сери muncul karena Adhisti Zara yang mengumbar video mesranya bersama Nico Al Hakim yang awalnya bersifat privasi karena hanya disebar pada fitur close friends di platform Instagram malah tersebar luas.

Istilah сери memiliki makna dalam bahasa gaul yang merujuk ke seseorang yang berperan sebagai tukang mengadu, lantaran sosok tersebut tidak bisa menjaga informasi maupun hal-hal penting dari teman juga para rekannya. Sehingga lebih layak untuk merepresentasikan seseorang yang membocorkan informasi pribadi seseorang dengan tujuan agar seseorang yang melakukan kesalahan tersebut menjadi dibenci atau disudutkan oleh lingkup lingkungan sosialnya.

Kemudian berdasarkan 6 keyword di atas, maka dapat dipetik bahwa rasa penasaran para warganet yang didominasi oleh kaum remaja merepresentasikan fenomena buruk yang ada di sekitarnya, kecuali ikoy-ikoyan. Hal ini pun dapat memicu terjadinya degradasi moral pada remaja karena mereka bersikap untuk lebih 
sensitif terhadap lingkungan tetapi cenderung mempertahankan ego mereka sendiri. Akhirakhir ini remaja menjadi lebih responsif terhadap isu-isu negatif yang menjadi seru apabila dilontarkan atau dikomunikasikan dengan orang-orang terdekat di lingkungan mereka. Lalu dari hal inilah yang mampu menciptakan stereotip negatif dari kejadian sekitar dan membangun citra negatif bagi seluruh kejadian di sekitar mereka. Hal-hal negatif selalu dianggap wajar, dan hal-hal positif pun semakin ditinggalkan.

Pada akhirnya hipotesis pada penelitian ini pun terjawab, bahwa etika dan moral sangat mempengaruhi daya tangkap remaja terhadap literasi digital. Individual competence yang dimiliki kaum remaja masa kini juga mampu melunturkan nilai kemampuan berpikir kritis yang dimiliki oleh remaja, sehingga mereka hanya merasakan lebih banyak dampak negatif daripada dampak positif dari kemajuan dunia digital.

Lalu dari beberapa keyword yang sudah dipaparkan sebelumnya, apabila rasa penasaran warganet diwarnai oleh isu fenomena negatif di sekitar mereka, juga merepresentasikan betapa mirisnya kehidupan di era digital ini. Hal-hal negatif malah cenderung dijadikan sebagai pedoman hidup, karena hal-hal positif dianggap sebagai hal yang kaku (lurus-lurus saja), tidak ada cobaan apapun dan kurang menantang.

Jangan biarkan teknologi semakin menguasai kehidupan manusia, tetapi pertahankanlah nilai humanis dan empiris manusia sebagai pengembang teknologi sekaligus pengendali teknologi. Karena apabila dunia ini semakin dikuasai oleh teknologi, maka akan menghilangkan nilai supremasi manusia sebagai makhluk yang relatif paling sempurna di dunia ini.

\section{KESIMPULAN}

\section{Simpulan}

Dari penelitian ini dapat disimpulkan bahwa degradasi etika maupun moral yang terjadi khususnya di kalangan remaja benarbenar menurunkan kualitas literasi di era digital. Sehingga hal ini menjadi peristiwa yang sangat memprihatinkan bagi kehidupan pemuda sebagai penerus bangsa apabila fenomena ini terus dibiarkan. Relasi manusia pun dijadikan sebagai relasi kebendaan, karena para warganet khususnya remaja lebih senang menikmati dunia maya daripada dunia nyata.

Nilai kemanusiaan pun semakin luntur apabila supremasi manusia di dunia dikalahkan oleh kemajuan teknologi. Manusia boleh saja memperbaiki sistem 
pendidikan dan sistem kerja mereka, tetapi jangan lupa untuk memprioritaskan etika dan moral sebagai fondasi falsafah hidup manusia sebagai makhluk hidup yang humanis.

\section{Saran}

Penelitian ini tentu saja memiliki kekurangan, sehingga diharapkan agar penelitian ini dapat menjadi referensi bagi penelitian selanjutnya yang lebih relevan. Tindakan nyata yang bisa diambil untuk mengatasi permasalahan di atas adalah dengan menanamkan wawasan kebangsaan baik itu secara teoritis dan praktis dalam rangka menciptakan generasi yang semakin unggul. Selain itu diharapkan para pemuda mengembangkan nilai individual competencenya terutama kemampuan dalam berpikir kritis sehingga mampu mengontrol utilitas gadget dengan optimal dan menyeleksi konten mana yang layak untuk dikonsumsi dan mana yang tidak layak. Peneliti berharap pada penelitian selanjutnya akan meneliti implikasi degradasi moralitas remaja terhadap perkembangan literasi digital di era post-pandemic.

\section{REFERENSI}

\section{Jurnal}

Adnyana, I. B. P. (2021). Filsafat Moral: Disequilibrium Citra dan Realita Etika Masyarakat Indonesia (Studi Fenomenologi Penggunaan Media
Sosial Instagram). Sanjiwani: Jurnal Filsafat, 12(2), 159-172. http://ejournal.ihdn.ac.id/index.php/San jiwani/article/view/2625

Agianto, R., Setiawati, A., \& Firmansyah, R. (2020). Pengaruh Media Sosial Instagram Terhadap Gaya Hidup dan Etika Remaja. TEMATIK - Jurnal Teknologi Informasi Dan Komunikasi, 7(2 SE-Articles), 130-139.

https://jurnal.plb.ac.id/index.php/temati k/article/view/461

Andriati, N., \& Hidayati, N. (2020).

Investigasi Pelaksanaan Bimbingan Kelompok Tentang Etika Pergaulan Siswa di Era Digital. JINOTEP (Jurnal Inovasi Dan Teknologi Pembelajaran): Kajian Dan Riset Dalam Teknologi Pembelajaran, 7(2), 116-123. https://doi.org/10.17977/um031v7i2202 $0 \mathrm{p} 116$

Ardian, Z., Sundani, S. A., \& Ningrum, E. S. (2019). Sosialisasi Penggunaan Media Sosial Secara Positif Dengan topik "Menjadi Remaja Cerdas Dalam Bermedia Sosial ” Di SMK Negeri 2 Banda Aceh Socialization Of Positive Use Of Social Media With The Topic Of "Being Intelingent Youth in Sosial Media " In Vocat. 1(2), 22-26.

Autoridad Nacional del Servicio Civil. (2021). 済無No Title No Title No Title. Angewandte Chemie International Edition, 6(11), 951-952., 8, 20132015.

Azizah, A. R. (2019). Volume 5 nomor 2, september 2019 33. Jurnal SKRIPTA: Jurnal Pembelajaran Bahasa Dan Sastra Indonesia, 5(2), 33-39.

Candrasari, Y. C., Dyva Claretta, \& Sumardjiajti. (2020). Pengembangan Dan Pendampingan Literasi Digital UntukPeningkatan Kualitas Remaja 
Dalam Menggunakan Internet.

Dinamisia: Jurnal Pengabdian Kepada Masyarakat, 4(4), 611-618.

https://doi.org/10.31849/dinamisia.v4i4 .4003

Dewi, P. Y. A. (2019). Gerakan Membaca

Di Awal Pelajaran Guna Membangun Budaya Literasi Di Sekolah Dasar. Journal of Chemical Information and Modeling, 53(9), 77-85.

http://jayapanguspress.penerbit.org/ind ex.php/PN/article/view/249

Di, D., \& Revolusi, E. R. A. (2019). Literasi Penyimpangan Nilai Moral Berkaitan Dengan Tanggung Jawab Dalam Novel Suti Karya Sapardi Djoko. 25-32.

Education, I. (n.d.). PERAN KEGIATAN LITERASI KARAKTER MAHASISWA PENDIDIKAN AGAMA ISLAM FTK-.

Fadhli, M., Pendidikan, S., Inggris, B., \& Keguruan, F. (2020). Jurnal Abdi Pendidikan Peningkatan Kesadaran Masyarakat dalam Menggunakan Bahasa yang Bijak di Media Sosial pada Era Digitalisasi.01(1), 25-31.

Fakhriati. (2021). Meningkatkan Ketrampilan Etika Pergaulan Melalui Layanan Bimbingan Kelompok Pada Siswa Kelas Xi Mipa-1 Sma Negeri 1 Glumpang Tiga Kabupaten Pidie. 11(September), 118-122.

Fatimah, M. M., Abdulkarim, A., \& Iswandi, D. (2020). Increasing Students Understanding of National Insights Through Digital Literacy in Civic Education Learning. Jurnal Civicus, 20(1), 31-39.

https://ejournal.upi.edu/index.php/civic us/article/view/16327

Fatmawati, E. (2020). Kebebasan Informasi Kalangan Milenial Dalam Ber-media Sosial. JPUA: Jurnal Perpustakaan
Universitas Airlangga: Media

Informasi Dan Komunikasi

Kepustakawanan, 10(2), 94.

https://doi.org/10.20473/jpua.v10i2.202

0.94-103

Febrianti, Y. F., \& Pulungan, R. (2021). Penggunaan Bahasa Gaul Terhadap Eksistensi Bahasa. Universitas Muslim Al-Washliyah, 2(1), 45.

Frederick, B., \& Maharani, A. K. (2021). Eksistensi media sosial pada masa pandemi covid-19. Jurnal Penelitian Pendidikan Sosial Humaniora, 6(2), 75-83.

Ghozali, I. (2019). Pendidikan Etika, Moral Dan Akhlak Dalam Kehidupan Remaja Islam Di Kecamatan Mulyorejo Kota Surabaya. Murabbi, 02(02). https://ejournal.stitalhikmahtt.ac.id/index.php/murabbi/article/view/ 44

Ihsani, A. F. A., \& Febriyanti, N. (2021). Etika Komunikasi Sebagai Kontrol Kesalehan Virtual dalam Perilaku Bermedia Masyarakat di Era Digital. Jurnal Al Azhar Indonesia Seri Ilmu Sosial, 2(1), 24. https://doi.org/10.36722/jaiss.v2i1.512

Kecemasan, M., \& Masa, D. I. (2021). Proceeding of The 1. 1, 545-563.

Krisdayanti, M. (2021). degradasi akhlak remaja dalam penggunaan media sosial.

Kusuma, R. (2020). Remaja digital: literasi dan etika. 1-19.

Linda Pradani Agesti, Rizki Fitryasari, NIi

Ketut Alit Armini, A. Y. (2019).

( Jurnal Keperawatan Jiwa)

HUBUNGAN SMARTPHONE ADDICTION DAN SELF-EFFICACY DENGAN. 1(1), 1-6.

http://repository.unair.ac.id/81028/ 
Lisnawati, L., Nugraha, D. M., \& . S. (2021). Pengaruh Media Sosial Terhadap Moral Remaja Pada Situasi Covid-19. Harmony: Jurnal Pembelajaran IPS Dan PKN, 6(1), 2025.

https://doi.org/10.15294/harmony.v6i1. 46844

Lubis, D., \& Siregar, H. S. (2020). Bahaya Radikalisme terhadap Moralitas Remaja melalui Teknologi Informasi (Media Sosial). APLIKASIA: Jurnal Aplikasi Ilmu-Ilmu Agama, 20(1), 2134.

Majid, M. N., \& Usman, M. (2020). Era Masyarakat Informasi. Jurnal Komunikasi Dan Penyiaran Islam, 01(1), 1-18.

http://ejournal.iaiuluwiyah.ac.id/index. php/maquro/article/view/139

Manuaba, I. B. P. (2019). Komunitas Sastra, Produksi Karya, dan Pembangunan Karakter. Mozaik Humaniora, 19(1), 37-47. https://ejournal.unair.ac.id/MOZAIK/article/vie w/10563

Marwan, S. (2020). Literasi Pembelajaran Online Berkearifan Lokal.

PROCEEDING IAIN Batusangkar, 1, 245-248.

https://core.ac.uk/download/pdf/328166 635.pdf

Meilinda, N., Malinda, F., \& Aisyah, S. M. (2020). Literasi Digital Pada Remaja Digital (Sosialisasi Pemanfaatan Media Sosial Bagi Pelajar Sekolah Menengah Atas). Jurnal Abdimas Mandiri, 4(1), 62-69. https://doi.org/10.36982/jam.v4i1.1047

Muannas, \& Mansyur, M. (2020). Model Literasi Digital untuk Melawan Ujaran Kebencian di Media Sosial. IPTEKKOM: Jurnal Ilmu Pengetahuan Dan
Teknologi Komunikasi), 22(2), 125142.

http://dx.doi.org/10.33164/iptekkom.22 .2.2020.125-142

Mudjiyanto, B., Dunan, A., Kunci, K., \& Pancasila, N. (n.d.). Implementasi nilai pancasila di saat pandemi covid-19. November 2020, 105-118.

Nugroho, C., \& Nasionalita, K. (2020). Digital Literacy Index of Teenagers in Indonesia. Journal Pekommas, 5(2), 215.

https://doi.org/10.30818/jpkm.2020.205 0210

Nur, I., \& Muttaqin, M. N. (2020). Bermedia Sosial dalam Perspektif Maqashid Syari'ah (Membangun Komunikasi di Media Sosial Berdasarkan Etika). Palita: Journal of Social Religion Research, 5(1), 1-14. https://doi.org/10.24256/pal.v5i1.1090

Nur Ika Fatmawati. (2019). Literasi Digital, Mendidik Anak Di Era Digital Bagi Orang Tua Milenial. Madani Jurnal Politik Dan Sosial Kemasyarakatan, 11(2), 119-138.

Nurahman, A., \& Purwaka, A. (2021). Pengaruh Bahasa Gaul Terhadap Penggunaan Bahasa Indonesia Pada Siswa Smp Nusantara Palangkaraya Tahun 2020. Jurnal Pendidikan, 21(2), 92-104.

https://doi.org/10.52850/jpn.v21i2.2019

Nurchayati, Z. (2019). Penguatan Etika Dalam Berkomunikasi Pada Remaja Di Kabupaten Madiun. Jurnal Daya-Mas, 4, 31-36.

http://dayamas.unmermadiun.ac.id/inde x.php/dayamas/article/view/16/0

Oktaviani Hidayat, D., Eltariant, I., Kevin Priyatna, R., \& Agustina Fernanda, S. (2019). Implementasi nilai-nilai 
pancasila dalam mencegah degradasi moral terhadap isu sara dan hoax. Jurnal Rontal Keilmuan PKN, 5, 50.

Palupi, M. F. T., \& Fitri, \& N. (2020). Edukasi Literasi Digital pada Remaja dalam Menangkal Cyberbullying. Jurnal Abdidas, 1(3), 761-769.

Pembinaan, P., Dan, E., Remaja, M., Desa, D., Bakbakan, P., \& Gianyar, K. (2021). Pola Pembinaan Etika Dan Moral Remaja Hindu Di Desa Pakraman Bakbakan, Kabupaten Gianyar. 1(1), 60-73.

Pengaruh PMA, PMDN, TK, dan I. (2020). No 主钼的健康感を中心とした在宅 高齢者における健康関連指標に関 する共分散構造分析Title. 2507(February), 1-9.

Permana, I. D. G. D. (2021). Menghadapi Degradasi Etika Dan Moral Sebagai Problematika Generasi Milenial Dengan Perspektif Pendidikan Agama Hindu. Guna Widya : Jurnal Pendidikan Hindu, 8(1), 46-64. http://ejournal.ihdn.ac.id/index.php/G W

Priambodo, G. A. (2019). Urgensi Literasi Media Sosial dalam Menangkal Ancaman Berita Hoax di Kalangan Remaja. Jurnal Civic Hukum, 4(2), 130-137.

Prihatini, M., \& Muhid, A. (2021). Literasi Digital terhadap Perilaku Penggunaan Internet Berkonten Islam di Kalangan Remaja Muslim Kota. Journal AnNafs: Kajian Penelitian Psikologi, 6(1), 23-40.

https://doi.org/10.33367/psi.v6i1.1307

Putra, A. S., \& Hartanto, B. H. (2020). Penggunaan Bahasa Prokem Pada Media Sosial Whats App Mahasiswa Universitas Muhammadiyah
Tangerang. Lingua Rima: Jurnal Pendidikan Bahasa Dan Sastra Indonesia, 9(1), 49. https://doi.org/10.31000/lgrm.v9i1.240 0

Qoni, N., Ilmu, D., Ilmu, F., Politik, I., \& Airlangga, U. (2020). Proses Konstruksi Indentitas Pembaca Karya Sastra Jawa di Kalangan Anak Muda Urban The Identity Construction Process of Readers of Jabanese Literature among Urban Young people Pendahuluan Dunia sastra dan budaya terus mengalami perkembangan di era modern . 11(2), 106-124.

Restu Yogi Fahlevi, Ah Yusuf, and I. K. (2020). FUNDAMENTAL AND MANAGEMENT Hubungan Cyberbullying dengan Kecemasan Sosial dan Penarikan. Fundamental and Managementnursing Journal, 3(2), 3845.

Ridlo, M., Satriyadi, Y., Azzahra, N., \& Nasution, A. H. (2021). Analisis Pengaruh Bahasa Gaul Di Kalangan Mahasiswa Terhadap Bahasa Indonesia Di Zaman Sekarang. Jurnal Kewarganegaraan, 5(2). https://doi.org/10.31316/jk.v5i2.1940

Risdiawati, D., \& Tulungagung, I. (2020). Urgensi Literasi Media bagi Pengembangan Pola Pikir Kehidupan Sosial Masyarakat. 2(2). http://ejournal.stainpamekasan.ac.id/ind ex.php/entitahttp://doi.org/10.19105/ejp is.

Ruteng, D. I. S. D. K., Rembong, K. L., Manggarai, K., \& Danu, A. K. (n.d.). Melalui Komunitas Sastra Anak. 2129.

SARI, S. (2019). Literasi Media Pada Generasi Milenial Di Era Digital. Profesional: Jurnal Komunikasi Dan 
Administrasi Publik, 6(2), 30-42. https://doi.org/10.37676/professional.v $6 \mathrm{i} 2.943$

Sari, S. P., \& Bermuli, J. E. (2021). Etika Kristen dalam Pendidikan Karakter dan Moral Siswa di Era Digital [Christian Ethics in Teaching Character and Moral for Students in the Digital Era]. Diligentia: Journal of Theology and Christian Education, 3(1), 46. https://doi.org/10.19166/dil.v3i1.2782

Sumanto, D., \& Nuraeni, D. (2020). Kontrol Sosial Orang Tua dalam Penggunaan Smartphone di Kalangan Remaja. Prosiding Seminar Nasional Pendidikan Pancasila Dan Kewarganegaraan, 1(1), 126-138.

Susanti, E. (2020). Sosialisasi Membangun Literasi Karakter Berbasis Pancasila di Era Digital 4.0 dalam Upaya Pencegahan Radikalisme dan Terorisme pada Remaja. Jurnal Sumbangsih, 1(1), 9-18. https://doi.org/10.23960/jsh.v1i1.3

Susanti, S., Adi Budiman, I., \& Mahpudin. (2021). Systematic literatur review : Dampak game online etika dan perilaku anak. Universitas Majalengka; Jl. Raya KH. Abdul Halim No, 103(0233), 634641.

Taopan, Y. F., Oedjoe, M. R., \& Sogen, A. N. (2019). Dampak Perkembangan Teknologi Informasi dan Komunikasi Terhadap Perilaku Moral Remaja di SMA Negeri 3 Kota Kupang. Jurnal Kependidikan: Jurnal Hasil Penelitian Dan Kajian Kepustakaan Di Bidang Pendidikan, Pengajaran Dan Pembelajaran, 5(1), 61. https://doi.org/10.33394/jk.v5i1.1395

Waruwu, M., Arifianto, Y. A., \& Suseno, A. (2020). Peran Pendidikan Etika Kristen dalam Media Sosial di Era Disrupsi.
Jurnal Pendidikan Agama Kristen (JUPAK), 1(1), 38-46. https://doi.org/10.52489/jupak.v1i1.5

Widiyono, S. (2019). pengembangan nasionalisme generasi muda di era globalisasi. 7, 12-21.

Wiguna, I. B. A. A., \& Dewi, K. A. T. R. (2020). Strategi Guru Dalam

Peningkatan Mutu Pembelajaran Etika Hindu. Jurnal Penjaminan Mutu, 6(2), 210-220.

Wijayanti, I. (2019). kemerosotan nilai moral yang terjadi pada generasi muda di era modern. 1-8.

Yunianto, D. (2020). Ketahanan Keluarga Sebagai Basis Pendidikan Di Tengah Pandemi Covid 19. TA 'DIBUNA: Jurnal Pendidikan Agama Islam, 3(1), 1. https://doi.org/10.30659/jpai.3.1.112

\section{Internet}

Google Trends. (2021). Lihat yang Trending di $2021 \quad-\quad$ Indonesia. https://trends.google.com/trends/yis/ 2021/ID/ Diakses pada 1 Januari 2022, 09:12 WIB.

Kementerian Komunikasi dan Informatika. (2021). Ada 37 Juta Pengguna Baru, Penting Pahami Literasi Digital. https://aptika.kominfo.go.id/2021/05/ ada-37-juta-pengguna-internet-barupenting-pahami-literasi-digital/ Diakses pada 1 Januari 2022, 06:49 WIB.

Kompas. (2021). Buat Penasaran, Apa Itu Ikoy Ikoyan? https://www.kompas.com/hype/read/ 2021/08/02/114500866/buatpenasaran-apa-itu-ikoy- 
ikoyan?page $=$ all Diakses pada 1 Januari 2022, 20:42 WIB.

Kompas TV. (2021). Kata Gelay Viral di Media Sosial Gegara diucapkan Nissa Sabyan, Ini Artinya. https://www.kompas.tv/article/15024 2/kata-gelay-viral-di-media-sosialgegara-diucapkan-nissa-sabyan-iniartinya Diakses pada 2 Januari 2022, 04:22 WIB.

Kumparan. (2021). Mengenal Arti Kata Cepu, Istilah Kekinian yang Populer di Medsos.

https://kumparan.com/hipontianak/m engenal-arti-kata-cepu-istilahkekinian-yang-populer-di-medsos1wEtkrDkxXz Diakses pada 2 Januari 2022, 04:51 WIB.

USS Feed. (2021). Arti Jamet, Kata yang Suka Muncul di Medsos. https://www.ussfeed.com/arti-jamet/

Diakses pada 2 Januari 2022, 04:12 WIB.

\section{Buku dan Kamus}

KBBI V. (online).

Oxford Dictionary (online).

Milles, B., Huberman, A. M. (2013). Analisis Data Kualitatif. Jakarta: UI Press.

Sugiyono. (2017). Metode Penelitian Kualitatif. Bandung: PT. Alfabeta. 